\title{
Cloning of genes for proline and leucine biosynthesis from Brucella abortus by functional complementation in Escherichia coli
}

\author{
Richard C. EssenberG* and Yogesh K. Sharma ${ }^{*}$ \\ Department of Biochemistry and Molecular Biology, Oklahoma State University, Stillwater, OK 74078, USA
}

(Received 20 July 1992; revised 25 September 1992; accepted 5 October 1992)

\begin{abstract}
By selecting for growth of Escherichia coli mutant strains in the absence of the required amino acid, clones were found in a Brucella abortus library carrying genes for glutamylphosphate reductase (pro $A$ ) and $\beta$-isopropylmalate dehydrogenase $(l e u B)$. These clones hybridized to unique fragments in a genomic digest of $B$. abortus DNA. The proA-complementing DNA was found in a region of $1.3 \mathrm{~kb}$, which directed the synthesis of a protein of $48000 \mathrm{Da}$ with a pI of 6.3 in maxicells. The leuB-complementing activity was in a region of $1.4 \mathrm{~kb}$ and directed synthesis of a protein of $46000 \mathrm{Da}$ with a pI of 5.9.
\end{abstract}

\section{Introduction}

Brucella abortus is usually considered a fastidious organism and is cultured on complex media, frequently including serum. Strains of Brucella have been found which will grow on defined media, in some cases using only ammonia as nitrogen source, but more often using a single amino acid (Gerhardt, 1958). That this can happen implies that Brucella must be able to synthesize virtually all amino acids. Species of Brucella are capable of surviving in macrophages and other cell types, and grow in enveloped vesicles in these cells. It is possible that some nutrients either in blood or the cytoplasm of the infected cells are unavailable in these vesicles, so in this state, the Brucella cells may have to use their ability to synthesize amino acids. Certain Salmonella auxotrophs, including ones for leucine, are less virulent in mice, suggesting these nutrients are not readily available to a pathogen living inside a phagosome (Bacon et al., 1951). The ability of $B$. abortus strain 19 to synthesize amino acids was tested by attempting to complement defects in various Escherichia coli mutants unable to synthesize amino acids and other nutrients. We report here the isolation of Brucella genes for proline and leucine biosynthesis.

\footnotetext{
* Author for correspondence. Tel. (405) 744 6193; fax (405) 744 6007.

† Present address: Biomedical Research and Development, The Jerome H. Holland Laboratory, Department of Cell Biology, American Red Cross, 15601 Crabs Branch Way, Rockville, MD 20855, USA.
}

\section{Methods}

Bacterial strains, plasmids and media. The E. coli strains used in this work are shown in Table 1. B. abortus strain 19 was obtained from the Oklahoma Animal Disease Diagnostic Laboratory (Oklahoma State Univ.). For DNA isolation, Brucella cells were grown on plates of tryptose medium (Difco) solidified with agarose. Routine culture of E. coli used LB (Luria \& Burrous, 1957). Transformants were selected on LM medium (Hanahan, 1983) containing $50 \mu \mathrm{g}$ ampicillin $\mathrm{ml}^{-1}$. Amino acid requirements were tested using medium A (Miller, 1972) with $10 \mathrm{~mm}$-glucose as carbon and energy source supplemented with the appropriate amino acids, bases and vitamins.

Strain RE484 was constructed from strain JM107 by introducing the phoA8 deletion from strain JF4281 by cotransduction with the transposon from strain $\chi 2844$. It was then made thy $A$ by selection for resistance to trimethoprim (Miller, 1972). Using strain WL66 as donor, $\operatorname{rec} B C$ was transduced in by selecting for Thy ${ }^{+}$. The strain was cured of $\operatorname{Tn} 10$ by selection for tetracycline sensitivity by the method of Maloy \& Nunn (1981). $s b c B$ was transduced from strain JC7623 by cotransduction with the his $G:: \operatorname{Tn} 10$ insertion from strain NK5526. Finally, the strain was transduced to $\mathrm{His}^{+}$, tetracycline sensitive from a wildtype donor.

Strains RE623, 625 and 799 were constructed from a derivative of $\chi 462$ in which the leuB2 lesion was replaced by wild-type by transduction, leaving the strain ara-14. The leuA,C and $D$ lesions from strains CV512, 522 and 526, respectively, were transduced in by selecting for $\mathrm{Ara}^{+}$. Finally, the $\operatorname{rec} A$ deletion was put in by mating with strain RE506 (RE799) or RE507 (RE623 and 625), selecting for tetracycline resistance.

General procedures. Cells were transformed by the PEG-DMSO method (Chung et al., 1989) unless very high efficiency was needed, in which case the method of Hanahan (1983) was used. Plasmids were isolated by the alkaline-SDS method (Ish-Horowicz \& Burke, 1981). Restriction enzymes were used under conditions specified by their manufacturers.

Construction of library. DNA was isolated from Brucella abortus strain 19 after growth on plates solidified with agarose to minimize 
Table 1. E. coli strains used

\begin{tabular}{|c|c|c|}
\hline Strain & Genotype & Source/reference* \\
\hline JM107 & $\begin{array}{l}\mathrm{F}^{\prime} \text { traD36 proA } B^{+} \text {lacI }{ }^{q} Z \Delta \mathrm{M} 15 / \Delta(\text { lac-pro }) \text { thi } \\
\text { gyr } A 96 \text { endA1 hsdR17 relA1 supE44 }\end{array}$ & $\begin{array}{l}\text { C. O. Gardner, } \mathrm{Jr}^{a} \text { (Yanisch- } \\
\text { Perron et al., 1985) }\end{array}$ \\
\hline JF4281 & $\begin{array}{l}\text { HfrC } \Delta p h o A 8 \text { fadL701 relA1 pit-10 spoT1 tonA22 } \\
\text { ompF627 } \lambda^{-}\end{array}$ & $\begin{array}{l}\text { J. D. Friesen }{ }^{b} \text { (Hayashi et al., } \\
\text { 1964) }\end{array}$ \\
\hline$\chi 2844$ & $t s x-462:: \operatorname{Tn} 10, \lambda^{-}$ & GCSC 6683 \\
\hline WL66 & $h s d R$ recB21C22 supE supF metB trpR & Amersham \\
\hline NK5526 & hisG213: :Tn $10 \mathrm{IN}(r r n D-r r n E 1) 1$ & CGSC 6416 \\
\hline RE484 & $\begin{array}{l}\mathrm{F}^{\prime} \text { traD36 pro } A B^{+} \text {lac }{ }^{q} Z \Delta \mathrm{M} 15 / \Delta(\text { lac-pro }) \text { thi } \\
\text { gyr } A 96 \text { endA1 hsdRI7 relAI supE } 44 \Delta \text { pho } A 8 \\
\text { recBC sbcB15 }\end{array}$ & See text \\
\hline JC7623 & $\begin{array}{l}\text { thr-1 ara-14 leuB6 } \Delta(\text { gpt-proA }) 62 \text { lacY1 tsx-33 } \\
\text { supE44 galK2 rac sbcB15 hisG4, rfbD1 recB21 } \\
\text { recC22 rpsL31 kdgK51 xyl-5 mtl-1 argE3 thi-1 }\end{array}$ & $\begin{array}{l}\text { CGSC } 5188 \text { (Kushner et al., } \\
\text { 1971) }\end{array}$ \\
\hline$\chi 462$ & $\begin{array}{l}\text { thi-1 metE70 lys A23 trpE38 purE42 proA leuB6 } \\
\text { mtl-1 xyl-5 ara-14 lacZ36 azi-6 rpsL109 tonA23 } \\
\text { tsx-67 supE44 }\end{array}$ & $\begin{array}{l}\text { M. C. Jones-Mortimer }{ }^{c} \text { (Berg \& } \\
\text { Curtiss, 1967) }\end{array}$ \\
\hline ED1032 & Hfr $\Delta(\mathrm{gpt}$-lac $) 5$ relA1 rpsE2123 thi-1 supE44 TP3 & CGSC 5395 (Broda et al., 1972) \\
\hline JC10289 & $\begin{array}{l}\text { thr-1 leuB6 } \Delta(\text { gpt-proA }) 62 \text { hisG } \Delta(\mathrm{rec} A-s r l R) 306 \\
\text { srlR301::Tn10-84 argE3 thi-1 ara-14 lacY1 } \\
\text { galK2 xyl-5 mtl-1 rpsL31 tsx-33 supE44 }\end{array}$ & $\begin{array}{l}\text { R. D. Porter }{ }^{d} \text { (Csonka \& Clark, } \\
\text { 1979) }\end{array}$ \\
\hline RE506 & $\begin{array}{l}\text { Hfr } \Delta(\text { gpt-lac }) 5 \text { relA1 rpsE2123 thi-1 supE44 TP3 } \\
\Delta(\text { recA-srlR } 306 \text { srlR301::Tn10-84 }\end{array}$ & $\begin{array}{l}\text { ED1032 transduced to } \mathrm{Tc}^{\mathrm{r}} \text { with } \\
\mathrm{P} 1 \text { grown on } \mathrm{JC10289}\end{array}$ \\
\hline RE521 & as $\chi 462$, but $\Delta(\operatorname{rec} A-s r l R) 306 \operatorname{srlR} 301:: \operatorname{Tn} 10-84$ & $\begin{array}{l}\chi 462 \text { mated with RE506, selecting } \\
\mathrm{Tc}^{\mathrm{r}}\end{array}$ \\
\hline$\chi 474$ & as $\chi 462$, but proB 91 & $\begin{array}{l}\text { CGSC } 6452 \text { (Berg \& Curtiss, } \\
1967)\end{array}$ \\
\hline RE603 & as $\chi 474$, but $\Delta(r e c A-s r l R) 306 \operatorname{srlR} 301:: \operatorname{Tn} 10-84$ & $\begin{array}{l}\chi 474 \text { mated with } \mathrm{RE} 506 \text {, selecting } \\
\mathrm{Tc}^{\mathrm{r}}\end{array}$ \\
\hline$\chi 478$ & as $\chi 462$, but proC 32 & $\begin{array}{l}\text { J. D. Friesen }{ }^{b} \text { (Berg \& Curtiss, } \\
\text { 1967) }\end{array}$ \\
\hline RE604 & as $\chi 478$, but $\Delta($ rec $A-s r l R) 306$ srlR301::Tn10-84 & $\begin{array}{l}\chi 478 \text { mated with } \mathrm{RE} 506, \text { selecting } \\
\mathrm{Tc}^{\mathrm{r}}\end{array}$ \\
\hline CV512 & $\mathrm{F}^{+} /$leuA371 & CGSC 5539 (Somers et al., 1973) \\
\hline RE623 & as RE521, but $\mathrm{ara}^{+}$leuA371 & See text \\
\hline CV522 & $\mathrm{F}^{+} /$leuC222 & CGSC 5543 (Somers et al., 1973) \\
\hline RE799 & as RE521, but $\mathrm{ara}^{+} \mathrm{leuC} 222$ & See text \\
\hline CV526 & $\mathrm{F}^{+} /$leuD101 & CGSC 5545 (Somers et al., 1973) \\
\hline RE625 & as RE521, but $\mathrm{ara}^{+}$leuD101 & See text \\
\hline CSR603 & $\begin{array}{l}\text { thr-1 leuB6 proA2 phr-1 recAl argE3 thi-1 uvrA6 } \\
\text { ara-14 lacY1 galK2 xyl-5 mtl-1 rpsL31 tsx-33 } \\
\text { supE44 }\end{array}$ & $\begin{array}{l}\text { J. D. Friesen }{ }^{b} \text { (Sancar \& Rupert, } \\
\text { 1978) }\end{array}$ \\
\hline
\end{tabular}

* Addresses: $a$, Oklahoma State Univ., Stillwater, OK, USA; $b$, Hospital for Sick Children, Toronto, Ont., Canada; $c$, Cambridge Univ., Cambridge, UK (present address: Hartsheath, Mold, Clwyd, UK); $d$, Pennsylvania State Univ., University Park, PA, USA).

extraction of inhibitors of restriction enzymes. Cells were washed off plates in $0.03 \mathrm{M}$-Tris/ $\mathrm{HCl}, 0.01 \mathrm{M}$-EDTA and $0.1 \mathrm{M}-\mathrm{NaCl}, \mathrm{pH} 8.2$, sedimented and resuspended in $9 \mathrm{ml}$ of the same buffer per plate. Lysozyme was added to $280 \mu \mathrm{g} \mathrm{ml}^{-1}$ and cells were digested at $37^{\circ} \mathrm{C}$ for several hours. Pronase was added $1 \mathrm{mg} \mathrm{ml}^{-1}$, RNAase to $100 \mu \mathrm{g} \mathrm{ml}^{-1}$ and SDS to $0.055 \%$, and digestion continued overnight at $37^{\circ} \mathrm{C}$. RNAase was then added to $160 \mu \mathrm{g} \mathrm{m}^{-1}$ and digestion continued at $37^{\circ} \mathrm{C}$ for $90 \mathrm{~min}$. Pronase $\left(35 \mu \mathrm{g} \mathrm{m}^{-1}\right)$ was added and digestion continued for $90 \mathrm{~min}$ at $37^{\circ} \mathrm{C}$. After addition of SDS to $1 \%$, the DNA was extracted twice with phenol and twice more with chloroform. The purified DNA was precipitated with ethanol. The DNA was digested with limiting amounts of restriction endonuclease EcoRI to produce fragments with an apparent average size on agarose gels of $2 \mathrm{~kb}$. Plasmid pUC9 (Vieira \& Messing, 1982) was digested to completion with $E c o$ RI and digested with calf intestine alkaline phosphatase. The two were ligated together in a $10 \mu 1$ mixture with cut and dephosphorylated pUC9 $\left(56 \mu \mathrm{g} \mathrm{m}^{-1}\right)$ and digested Brucella DNA (either 60 or $\left.120 \mu \mathrm{g} \mathrm{ml}^{-1}\right)$. After incubation at $15^{\circ} \mathrm{C}$ overnight, the mixture was transformed (Hanahan, 1983) into E. coli strain RE484. Transformants were plated on LM plates containing $50 \mu \mathrm{g}$ ampicillin $\mathrm{ml}^{-1}, 33 \mu \mathrm{g} 5$ bromo-4-chloro-3-indolyl $\beta$-D-galactoside $\mathrm{ml}^{-1}$ and $33 \mu \mathrm{M}$-isopropyl $\beta$ D-thiogalactoside. A total of 1800 colonies was plated, of which twothirds had inserts. Plates were scraped and plasmids isolated by the alkaline-SDS method (Ish-Horowicz \& Burke, 1981).

Enzyme assays. $\gamma$-Glutamylphosphate reductase was assayed by the procedure of Hayzer \& Leisinger (1980), after separation from 1pyrroline-5-carboxylate reductase on DEAE-cellulose. Cells were grown overnight on LB, harvested, washed in $50 \mathrm{~mm}-\mathrm{Tris} / \mathrm{HCl}, \mathrm{pH} 7 \cdot 2$ containing $1 \mathrm{~mm}$-DTT, then resuspended in $1 / 100$ volume of the same buffer. This concentrated cell suspension was sonicated for $60 \mathrm{~s}$ in $15 \mathrm{~s}$ bursts with $30 \mathrm{~s}$ cooling periods. Cell debris and unbroken cells were removed by centrifugation at $27000 \mathrm{~g}$ for $15 \mathrm{~min}$. DL-1-Pyrroline-5carboxylate was synthesized by the method of Williams \& Frank (1975). $\beta$-Isopropylmalate dehydrogenase was assayed by the method of Searles \& Calvo (1988), except that sonic extracts of strains were 
used. Cells were grown on minimal medium containing leucine to a Klett reading of 100 (red filter), then washed and resuspended in fresh minimal medium lacking leucine. They were starved with shaking at $37^{\circ} \mathrm{C}$ for $2 \mathrm{~h}$, then harvested, washed and resuspended in 0.075 vols $50 \mathrm{~mm}$-potassium phosphate buffer, $\mathrm{pH} 7 \cdot 4$. The cells were sonicated and centrifuged as above. $\beta$-Isopropylmalate was a generous gift from J. M. Calvo. Protein was determined by the dye binding assay of Bradford (1976), using bovine serum albumin as standard.

Subcloning and deletion construction. Plasmids were digested with restriction enzymes to generate the desired fragments and these were separated on low melting point agarose (Sea-Plaque, FMC) gels. The fragments were identified by fluorescence and cut out. If used, a vector was similarly cut and electrophoresed and excised. Ligation was done in melted agarose (Murray, 1986). The constructions were confirmed by restriction mapping. Phenotypes were determined by growth on minimal media after transformation into the appropriate strains.

Deletions were constructed in pBluescript subclones by digestion from either end of the insert using exonuclease III and mung bean nuclease (Heinrich, 1988). The $3^{\prime}$ overhang was generated using ApaI or Sacl depending on which end was to be deleted. The $5^{\prime}$ overhang was generated with the cloning enzyme, if possible, or any other in the multi-cloning site in the appropriate location. After ligation, the plasmids were transformed into RE521. The extent of the deletion was determined by digestion with $P v u I I$, then more accurately with $B g / I$. Phenotypes were determined by growth on appropriately supplemented minimal media.

Genomic digests and hybridization to cloned genes. B. abortus strain 2308 cells were encapsulated in agarose (InCert, FMC) beads (Jackson \& Cook, 1985) and digested to free the chromosomal DNA (Smith \& Cantor, 1987). The cells from one plate were encapsulated in approximately $1 \mathrm{ml}$ of beads. The encapsulated DNA was digested in a sample of beads with restriction endonucleases $X h o \mathrm{I}, X b a \mathrm{I}$ or both after soaking the beads in the recommended buffer three times for $15 \mathrm{~min}(200 \mu \mathrm{l}$ beads were digested with 50 units enzyme overnight at $37^{\circ} \mathrm{C}$ ). DNA bands were separated by field inversion gel electrophoresis (Carle et al., 1986) at $12{ }^{\circ} \mathrm{C}$ in $7.5 \times 15 \mathrm{~cm} 1 \%$ agarose gels at $4.6 \mathrm{~V} \mathrm{~cm}^{-1}$ using reversal times increasing linearly from $1.5 \mathrm{~s}$ forward $/ 0.5 \mathrm{~s}$ reverse to $21 \mathrm{~s}$ forward $/ 7 \mathrm{~s}$ reverse over $18 \mathrm{~h}$. Bands were visualized after staining in $0.5 \mu \mathrm{g}$ ethidium bromide $\mathrm{ml}^{-1}$. A bacteriophage $\lambda$ ladder for molecular mass calibration was made by

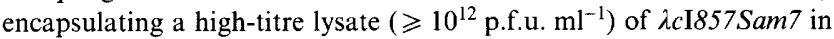
agarose beads and digesting with $50 \mu \mathrm{g}$ proteinase $\mathrm{K} \mathrm{ml}^{-1}$ in $0.5 \mathrm{M}$ EDTA, pH 8.0, $1 \% \mathrm{~N}$-lauroylsarcosine. In other experiments, Brucella DNA was digested with restriction enzymes and run on $0.8 \%$ agarose under normal constant voltage conditions, then transferred and hybridized as described.

The DNA was transferred to nylon (Nytran; Scheicher and Schuell) in base (Chomczynski \& Qasba, 1984) and hybridized to plasmid clones labelled with biotin using a photoactivated reagent (Sigma) (Forster $e t$ al., 1985) in $50 \%$ formamide, $6 \times \operatorname{SSPE}(1 \times \operatorname{SSPE}$ is $0.18 \mathrm{M}-\mathrm{NaCl}$, $10 \mathrm{~mm}$-sodium phosphate, $\mathrm{pH} 7 \cdot 7,1 \mathrm{~mm}$-EDTA) at $42^{\circ} \mathrm{C}$ overnight. The blot was washed with a final high stringency wash in $0.16 \times$ SSPE at $65^{\circ} \mathrm{C}$ twice for $15 \mathrm{~min}$. The location of hybridizing bands was detected with the BlueGene detection kit (BRL).

Identification of gene products in maxicells. Plasmids were transformed into strain CSR603, and proteins expressed after UV irradiation labelled with a ${ }^{35} \mathrm{~S}$ protein labelling mix $\left(\right.$ Expre $^{35} \mathrm{~S}^{35} \mathrm{~S}$, New England Nuclear) (Sancar et al., 1981). Proteins were separated by onedimensional SDS-PAGE on $12 \%$ gels (Laemmli, 1970) or by twodimensional gel electrophoresis (Ames \& Nikaido, 1976). Onedimensional gels were loaded with equal amounts of radioactivity in each lane. Gels were soaked in Autofluor (National Diagnostics) and exposed to Kodak XAR-5 film at $-70^{\circ} \mathrm{C}$.

\section{Results}

Isolation of clones complementing amino acid biosynthesis deficiencies

A library of $B$. abortus strain 19 genomic DNA was transformed into $E$. coli strain RE521, which has several deficiencies in amino acid and nucleotide biosynthesis. Clones able to grow in the absence of proline or leucine arose with a frequency of $5 / 8500$, while $0 / 8500$ could grow without adenine or lysine. On rough restriction mapping the proline-complementing clones appeared to be the same, as did the leucine-complementing ones. One proA-complementing clone was chosen and numbered pRE63, and one leuB-complementing clone was numbered pRE64. These clones could complement the deficiencies in strain JC10289, but, curiously, not the identical alleles in strain JC7623. Assay demonstrated that pRE63 restored activity for $\gamma$-glutamylphosphate reductase (EC 1.2.1.41) in strain RE521 (Table 2) and that pRE64 restored activity for $\beta$-isopropylmalate dehydrogenase (EC 1.1.1.85, Table 3).

These clones were tested to see if they carried any other genes in the pathway. pRE63 failed to complement the proB strain RE603 or proC strain RE604. pRE64 failed to complement leuA strain RE623, leuC strain RE799 or leuD strain RE625.

Table 2. $\gamma$-Glutamylphosphate reductase activity in E. coli RE521 carrying Brucella clones

Values are means $\pm \mathrm{SE}$.

\begin{tabular}{|c|c|}
\hline Plasmid & $\begin{array}{c}\text { Activity } \\
{\left[\mu \mathrm{mol} \min ^{-1}(\text { mg protein })^{-1}\right]}\end{array}$ \\
\hline pBluescript & $-0.08 \pm 0 \cdot 02(n=3)$ \\
\hline pRE63 & $0.97 \pm 0.18(n=4)$ \\
\hline pRE93 & $0 \cdot 73 \pm 0 \cdot 05(n=4)$ \\
\hline W3110* & $0.79 \pm 0.11(n=4)$ \\
\hline
\end{tabular}

* Wild-type strain W3110 carrying no plasmid.

Table 3. $\beta$-Isopropylmalate dehydrogenase activity in E. coli RE521 carrying Brucella clones

Values are means $\pm \mathrm{SE}$

\begin{tabular}{lc}
\hline \hline Plasmid & $\begin{array}{c}\text { Activity } \\
{\left[\mathrm{nmol} \mathrm{min}{ }^{-1}(\mathrm{mg} \text { protein })^{-1}\right]}\end{array}$ \\
\hline pBluescript & $1 \cdot 9 \pm 0 \cdot 2(n=8)$ \\
pRE64 & $58 \cdot 0 \pm 2 \cdot 3(n=8)$ \\
pRE89 & $22 \cdot 3 \pm 0 \cdot 3(n=8)$ \\
W3110* & $58 \cdot 6 \pm 1 \cdot 6(n=8)$ \\
\hline \hline
\end{tabular}

* Wild-type strain W3110 carrying no plasmid. 


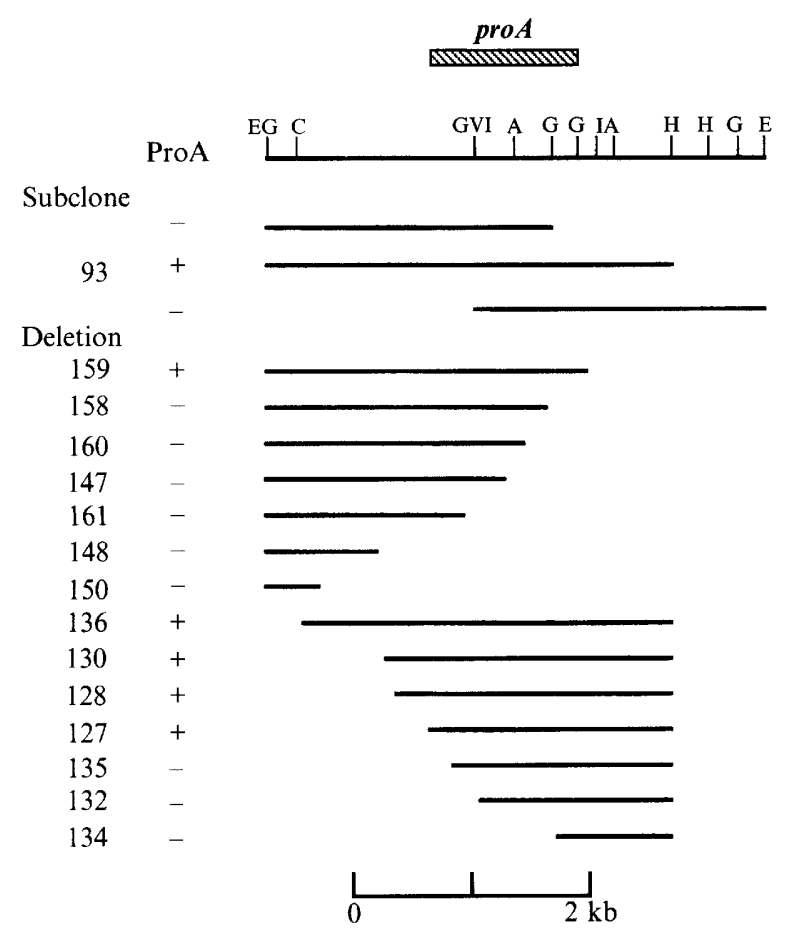

Fig. 1. Map of pRE63, subclones and deletions. The top line is a restriction map of the Brucella DNA insert of pRE63, showing sites for cleavage by $A f l \mathrm{III}(\mathrm{A}), C l a \mathrm{I}(\mathrm{C}), \operatorname{Eco} \mathrm{RI}(\mathrm{E}), B g I \mathrm{I}(\mathrm{G}), \operatorname{HindIII}(\mathrm{H})$, $H i n c I I$ (I) and PvuII (V). Next is shown the extent of the subclones, then the extents of the ExoIII-generated deletions of pRE93. The ProA phenotype conferred on strain RE521 is indicated for each subclone or deletion. The hatched box shows the inferred extent of the Brucella proA gene.

\section{Mapping and characterization of genes}

The clones were mapped with restriction enzymes as shown in Fig. 1 for pRE63 and Fig. 2 for pRE64. Various fragments were isolated and recloned to localize the genes on these plasmids. From Fig. 1, one can see that the pro $A$-complementing region of pRE63 was on a $3300 \mathrm{bp}$ EcoRI-HindIII fragment (subcloned as pRE93). This fragment could complement the proA mutation in both orientations with respect to the vector. It also restored $\gamma$-glutamylphosphate reductase activity to strain RE521. The complementing region was further localized by making deletions from each end. pRE127, with $1390 \mathrm{bp}$ deleted from the $E c o \mathrm{RI}$ site, was still $\mathrm{Pro}^{+}$, but pRE135, with 1590 bp deleted, was not. All deletions from the HindIII end were $\mathrm{Pro}^{-}$, except the $700 \mathrm{bp}$ deletion of pRE159. The leuB-complementing activity of pRE64 was found on the $2020 \mathrm{bp}$ HindIII-NheI fragment (Fig. 2 ). This fragment likewise could complement the leuB mutation in either orientation and restore enzyme activity to strain RE521. Deletions of $590 \mathrm{bp}$, but not $1140 \mathrm{bp}$ from the HindIII site retained it. All deletions from the NheI end were $\mathrm{Leu}^{-}$.

B. abortus DNA was encapsulated in agarose, digested with $X h o \mathrm{I}$ and $X b a \mathrm{I}$ and separated by field-inversion gel electrophoresis. Southern blots localized DNA found in pRE63 and 64 to single bands in each single digest and the double digest. In other experiments, these plasmids hybridized with single EcoRI fragments of the expected size.
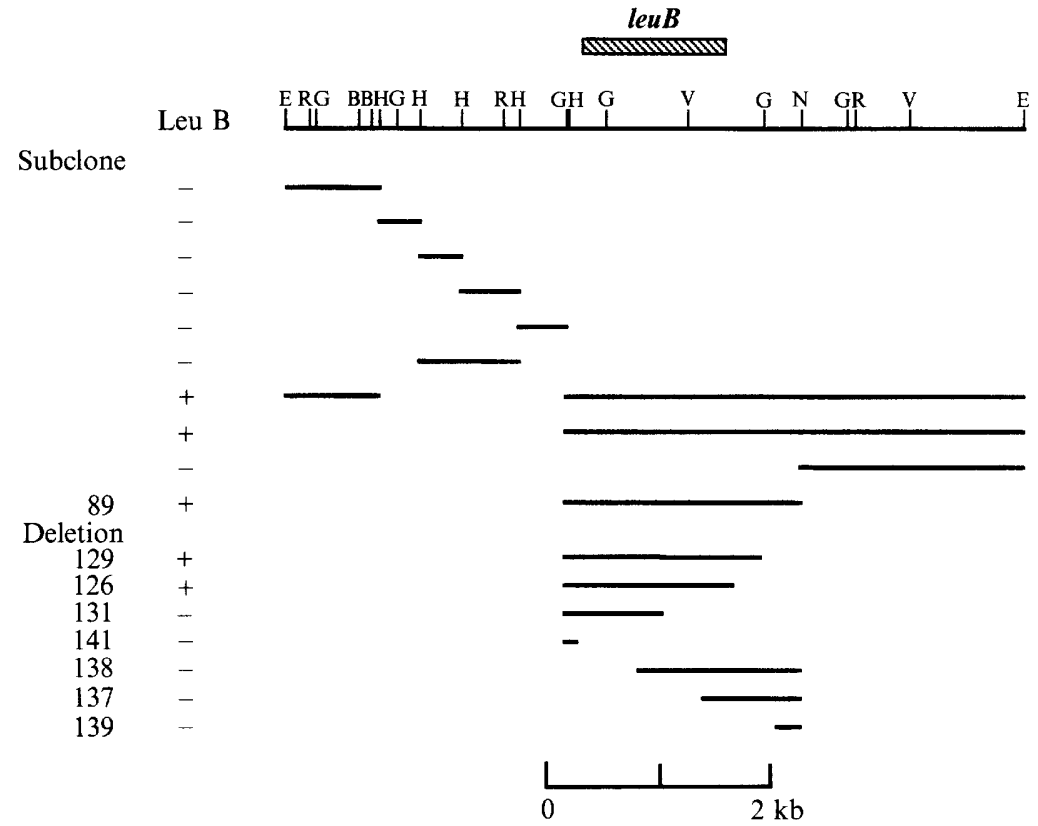

Fig. 2. Map of pRE64, subclones and deletions. The top line is a restriction map of the Brucella DNA insert in pRE64, showing sites for cleavage by enzymes as given in Fig. 1 except BamHI (B), NheI (N), PvuI (V) and RsaI (R). The extent of subclones and ExolIIgenerated deletions of pRE89 are indicated below. The LeuB phenotype conferred on strain RE521 is indicated. The hatched box shows the inferred extent of the Brucella leuB gene. 

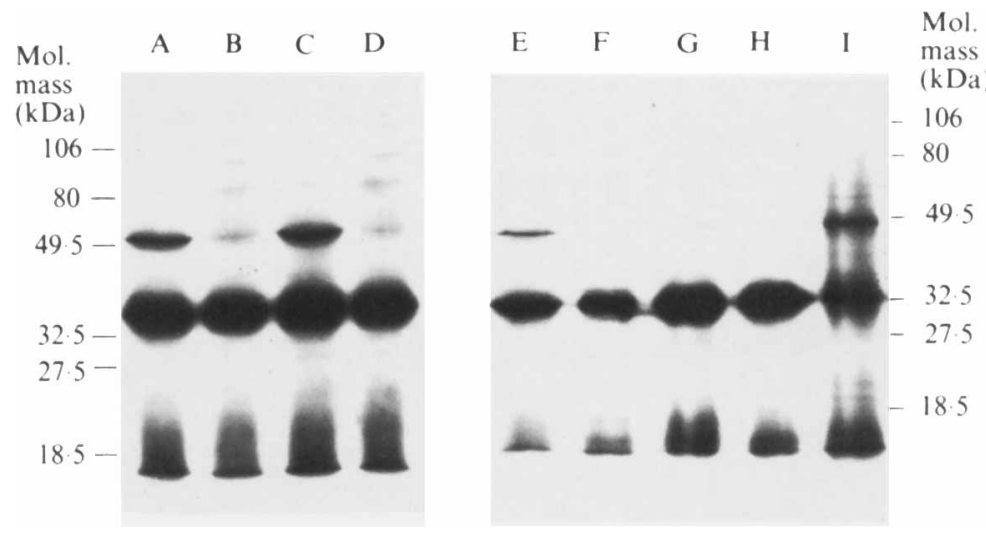

Fig. 3. One-dimensional SDS-PAGE of proteins labelled in maxicells containing pRE93 and various deletions. The positions of the prestained protein standards and their apparent molecular masses are indicated. Plasmids were pRE93 (lanes A and I), pRE158 (B and G), pRE159 (C), pRE160 (D), pRE127 (E), pBluescript (F) and pRE135 (H).
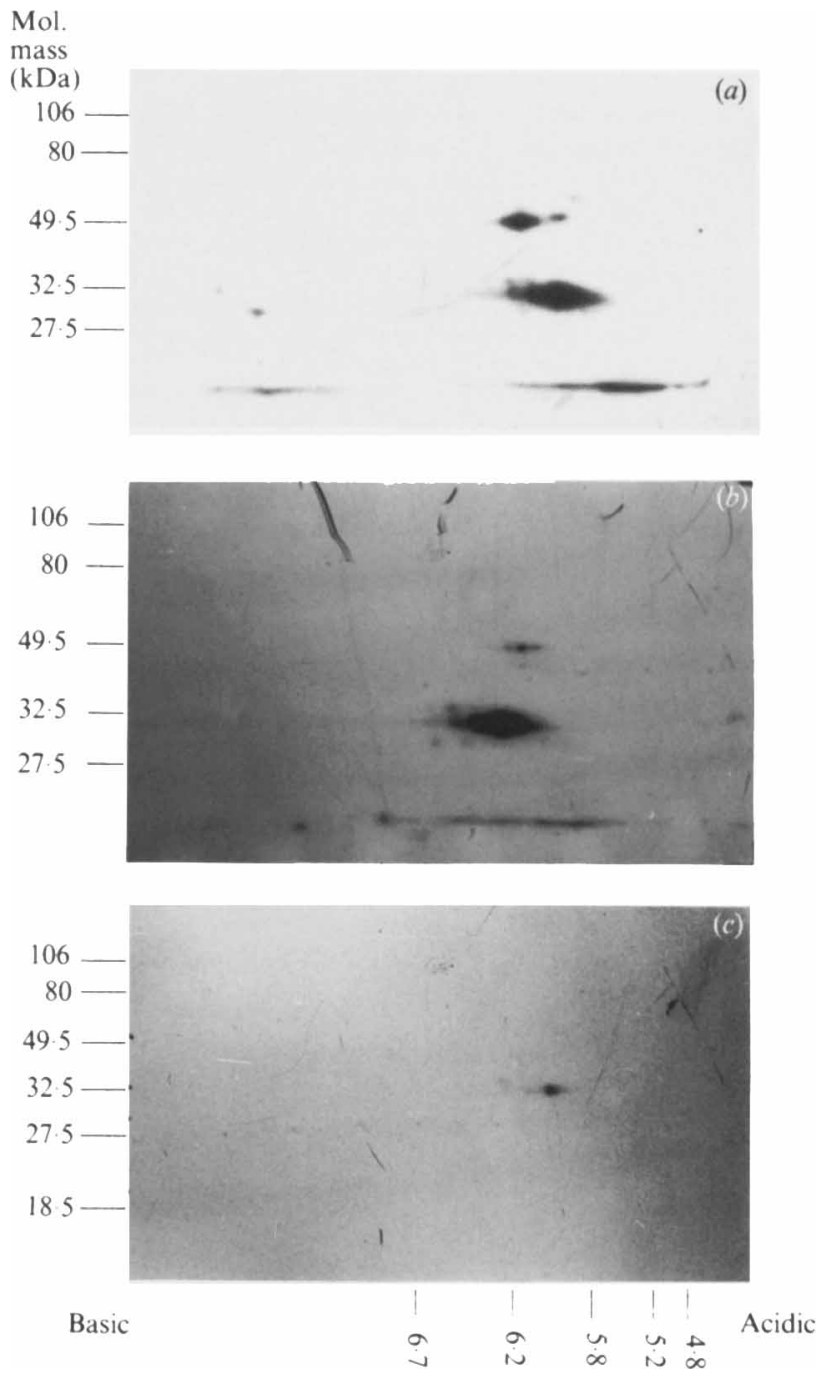

Fig. 4. Two-dimensional gel electrophoresis of proteins labelled in maxicells containing pRE93 (a), pRE89 $(b)$ and pBluescript $(c)$. The positions and apparent molecular masses of the prestained protein standards are shown. The position and $\mathrm{pI}$ of the first, sixth, eleventh, sixteenth and eighteenth [for $(a)$ and $(c)$ only] carbamylated carbonic anhydrase spots are indicated at the bottom of each gel.

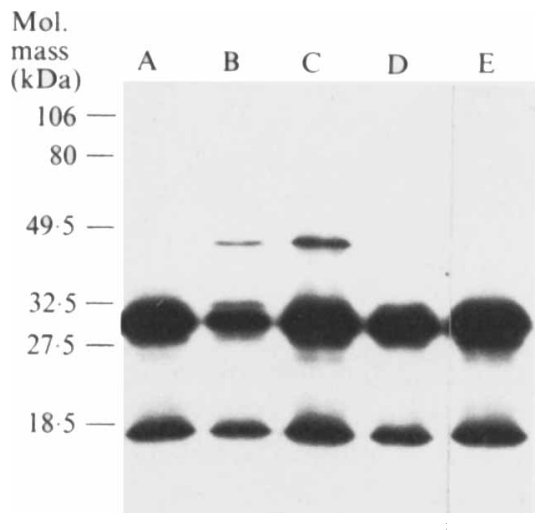

Fig. 5. One-dimensional SDS-PAGE of proteins labelled in maxicells containing pRE89 and various deletions. The positions of the prestained protein standards and their apparent molecular masses are indicated. Plasmids used were pBluescript (lane A), pRE89 (B), pRE126 (C), pRE131 (D) and pRE138 (E).

\section{Identification of gene products}

In maxicells, pro $A$ subclone pRE93 directed the synthesis of $\beta$-lactamase and another protein at $48000 \mathrm{Da}$ (Fig. 3). On two-dimensional gels, this protein had an isoelectric point similar to that of $\beta$-lactamase (Fig. 4). In deletion strains, the 48000 Da protein was present in those strains that were $\mathrm{Pro}^{+}$and not in those that were $\mathrm{Pro}^{-}$. The leuB subclone pRE89 gave a protein of $46000 \mathrm{Da}$ in addition to $\beta$-lactamase on one-dimensional gels (Fig. 5). This protein was much fainter than $\beta$-lactamase. On twodimensional gels, the 46000 Da protein was neutral, like $\beta$-lactamase. In deletions, the presence of the $46000 \mathrm{Da}$ protein was correlated with the ability of the clone to complement leuB.

\section{Discussion}

A few genes have been cloned previously from Brucella abortus. These include genes for proteins expected to be 
antigens, such as the porin in the outer membrane (Ficht et al., 1988) and proteins released by high salt wash (Mayfield et al., 1988). One enzyme, superoxide dismutase, has also been cloned (Bricker et al., 1990), but its identity was discovered by sequencing. The present report is the first to describe the cloning of Brucella genes by functional complementation.

The proA and $\operatorname{leu} B$ genes have been isolated from a number of bacteria, largely because the commonly used cloning strain HB101 carries these lesions. In most cases, only the cloning was noted, but a few of the genes have been studied in some detail. DNA sequences have been obtained for proA from Serratia marcescens (Omori et al., 1991) and E. coli (Deutch et al., 1984), and for leuB from several organisms (Sekiguchi et al., 1986, 1987; Imai et al. 1987; Kirino \& Oshima, 1991). We have isolated $B$. abortus DNA clones that restore enzyme activity for $\gamma$-glutamylphosphate reductase and $\beta$-isopropylmalate dehydrogenase in $E$. coli strains deficient in these enzymes. These enzymes are expressed from Brucella promoters at a rate sufficient to give activity similar to that of the $E$. coli enzyme in wild-type cells. These clones direct the synthesis of proteins of $48000 \mathrm{Da}$ for proA and $46000 \mathrm{Da}$ for leuB. The gene is about $1300 \mathrm{bp}$ for proA, which is what would be expected for a protein of the size seen. The protein is similar in size to the subunit molecular mass of $42000 \mathrm{Da}$ seen for the $E$. coli enzyme (Hayzer \& Leisinger, 1982) or $44000 \mathrm{Da}$ for the Serratia enzyme (Omori et al., 1991). For leuB, the gene is $1400 \mathrm{bp}$, which could code for a protein of $51000 \mathrm{Da}$, more than the $46000 \mathrm{Da}$ observed. This is somewhat larger than the subunit molecular mass of 35000 Da reported for E. coli (Parsons \& Burns, 1969) or 40000 Da for B. coagulans (Sekiguchi et al., 1986).

In $E$. coli and Salmonella typhimurium, the leucine genes are arranged in a single operon (Umbarger, 1987). We found no evidence of any gene but $l e u B$ on our clone, though it extends far enough in both directions that one would expect to detect other genes if they were present. This suggests the arrangement of genes in Brucella is diferent from that in $E$. coli. Likewise, pro $A$ and $B$ are adjacent in E. coli and S. typhimurium (Leisinger, 1987) and in S. marcescens (Omori et al., 1991), but again, there is no evidence for pro $B$ on our pro $A$ clone.

The presence of these enzymes suggests that $B$. abortus, like most bacteria, has the isopropylmalate pathway for leucine biosynthesis (Stieglitz \& Calvo, 1974). Likewise, it would appear to possess the $\gamma$-glutamylphosphate pathway for proline biosynthesis (Csonka \& Baich, 1983). Since B. abortus strain 19 has these two enzymes, it seems very likely that it can synthesize proline and leuine. It will be interesting to determine what controls operate in these pathways in this intracellular pathogen.
We thank Debra Phelps for competent technical assistance. This work was supported by USDA grants USDA-86-CRCR-1-2209 and USDA-ARS \# 58-5114-9-1008 and the Oklahoma Agricultural Experiment Station, of which this is paper $\mathbf{J}-6276$.

\section{References}

Ames, G. F.-L. \& NiKaido, K. (1976). Two-dimensional gel electrophoresis of membrane proteins. Biochemistry 15, 616-622.

Bacon, G. A., Burrows, T. W. \& Yates, M. (1951). The effects of biochemical mutation on the virulence of Bacterium typhosum: the virulence of mutants. British Journal of Experimental Pathology 31, $714-724$.

BERG, C. M. \& CuRTiss, R., III (1967). Transposition derivatives of an Hfr strain of Escherichia coli K-12. Genetics 56, 503-525.

BRADFORD, M. M. (1976). A rapid and sensitive method for the quantitation of microgram quantities of protein utilizing the principle of protein-dye binding. Analytical Biochemistry 72, 248-254.

Bricker, B. J., Tabatabai, L. B., Judge, B. A., Deyoe, B. L. \& MAYFIELd, J. E. (1990). Cloning, expression and occurrence of the Brucella $\mathrm{Cu}-\mathrm{Zn}$ superoxide dismutase. Infection and Immunity $\mathbf{5 8}$ 2935-2939.

Broda, P., Meacock, P. \& AChtman, M. (1972). Early transfer of genes determining transfer functions by some $\mathrm{Hfr}$ strains in Escherichia coli K12. Molecular and General Genetics 116, 336-347.

Carle, G. F., Frank, M. \& Olson, M. V. (1986). Electrophoretic separations of large DNA molecules by periodic inversion of the electric field. Science 232, 65-68.

Chomczynski, P. \& QASBA, P. K. (1984). Alkaline transfer of DNA to plastic membrane. Biochemical and Biophysical Research Communications 122, 340-344.

Chung, C. T., Niemela, S. L. \& Miller, R. H. (1989). One-step preparation of competent Escherichia coli: transformation and storage of bacterial cells in the same solution. Proceedings of the National Academy of Sciences of the United States of America 86, 2172-2175

Csonka, L. N. \& BaICH, A. (1983). Proline biosynthesis. In Amino Acids: Biosynthesis and Genetic Regulation, pp. 35-51. Edited by K. M. Herrmann \& R. L. Somerville. Reading, MA: Addison-Wesley.

Csonka, L. N. \& Clark, A. J. (1979). Deletions generated by the transposon $\mathrm{Tn} 10$ in the $s r l$ recA region of the Escherichia coli $\mathrm{K} 12$ chromosome. Genetics 93, 321-343.

Deutch, A. H., Rushlow, K. E. \& SMITh, C. J. (1984). Analysis of the Escherichia coli proAB locus by DNA and protein sequencing. Nucleic Acids Research 12, 6337-6355.

Ficht, T. A., Bearden, S. W., Sowa, B. A. \& Adams, L. G. (1988). A 36-kilodalton Brucella abortus cell envelope protein is encoded by repeated sequences closely linked in the genomic DNA. Infection and Immunity 56, 2036-2046.

Forster, A. C., McInnes, J. L., Skingle, D. C. \& Symons, R. H. (1985). Non-radioactive hybridization probe prepared by the chemical labelling of DNA and RNA with a novel reagent, photobiotin. Nucleic Acids Research 13, 745-761.

GerhardT, P. (1958). The nutrition of Brucellae. Bacteriological Reviews 22, 81-98.

Hanahan, D. (1983). Studies on transformation of Escherichia coll with plasmids. Journal of Molecular Biology 166, 557-580.

Hayashi, S., Koch, J. P. \& Lin, E. C. C. (1964). Active transport of L$\alpha$-glycerol phosphate in Escherichia coli. Journal of Biological Chemistry 239, 3098-3105.

HAYzer, D. J. \& LeISINGER, T. (1980). The gene enzyme relationships of proline biosynthesis in Escherichia coli. Journal of General Microbiology 118, 287-293.

Hayzer, D. J. \& Leisinger, T. (1982). Proline biosynthesis in Escherichia coli. Purification and characterization of glutamate semialdehyde dehydrogenase. European Journal of Biochemistry 121, 561-565.

HEINRICH, P. (1988). Construction of nested deletions for DNA sequencing. In Current Protocols in Molecular Biology, I, Supplement 
2, pp. 7.3.1-7.3.20. Edited by F. M. Ausubel, R. Brent, R. E. Kingston, D. D. Moore, J. G. Seidman, J. A. Smith \& K. Struhl. New York: John Wiley.

ImaI, R., SAKIGUCHI, T., Nosoh, Y.\& Tsuda, K. (1987). The nucleotide sequence of 3-isopropylmalate dehydrogenase gene from Bacillus subtilis. Nucleic Acids Research 15, 4988.

Ish-Horowicz, D. \& BURKE, J. F. (1981). Rapid and efficient cosmid cloning. Nucleic Acids Research 9, 2989-2998.

JACKSON, D. A. \& COOK, P. R. (1985). A general method for preparing chromatin containing intact DNA. EMBO Journal 4, 913-918.

Kirino, H. \& Oshima, T. (1991). Molecular cloning and nucleotide sequence of 3-isopropylmalate dehydrogenase gene $(l e u B)$ from an extreme thermophile, Thermus aquaticus YT-1. Journal of Biochemistry (Japan) 109, 852-857.

Kushner, S. R., Nagaishi, H., Templin, A. \& Clark, A. J. (1971). Genetic recombination in Escherichia coli: the role of exonuclease I. Proceedings of the National Academy of Sciences of the United States of America 68, 824 827.

LAEMMLI, U. K. (1970). Cleavage of structural proteins during the assembly of the head of bacteriophage T4. Nature, London 227, 680-685.

LEISINGER, T. (1987). Biosynthesis of proline. In Escherichia coli and Salmonella typhimurium. Cellular and Molecular Biology, vol. 1, pp. 345-351. Edited by F. C. Neidhardt and others. Washington, DC: American Society for Microbiology.

Luria, S. E. \& Burrous, J. W. (1957). Hybridization between Escherichia coli and Shigella. Journal of Bacteriology 97, 461-476.

MaLOY, S. R. \& NunN, W. D. (1981). Selection for loss of tetracycline resistance by Escherichia coli. Journal of Bacteriology 145, 1110-1112.

Mayfield, J. E., Bricker, B. J., Godfrey, H., Crosby, R. M., KNIGHT, D. J., Halling, S. M., Balinsky, D. \& Tabatabai, L. B. (1988). The cloning, expression, and nucleotide sequence of a gene coding for an immunogenic Brucella abortus protein. Gene 63, 1-9.

Miller, J. H. (1972). Experiments in Molecular Genetics. Cold Spring Harbor, NY: Cold Spring Harbor Laboratory.

Murray, J. A. H. (1986). HCC ligation: rapid and specific DNA construction with blunt ended DNA fragments. Nucleic Acids Research 14, 10118.

Omori, K., Suzuki, S. I., Imai, Y. \& Komatsubara, S. (1991). Analysis of the Serratia marcescens pro $A B$ operon and feedback control of proline biosynthesis. Journal of General Microbiology 137, 509-517.
Parsons, S. J. \& Burns, R. O. (1969). Purification and properties of $\beta$ isopropylmalate dehydrogenase. Journal of Biological Chemistry 244. 996-1003.

SANCAR, A. \& RUPERT, C. S. (1978). Correction for the map location for the phr gene in Escherichia coli K12. Mutation Research 51 , 139-143.

Sancar, A., Wharton, R. P., Seltzer, S., Kacinsky, B. M., Clarke, N. D. \& RupP, W. D. (1981). Identification of the uvrA gene product. Journal of Molecular Biology 148, 45-62.

Searles, L. L. \& Calvo, J. M. (1988). Permeabilized cell and radiochemical assays for $\beta$-isopropylmalate dehydrogenase. Methods in Enzymology 166, 225-229.

Sekiguchi, T., Ortega-Cesena, J., Nosoh, Y., Ohashi, S., Tsuda, K. \& KANAYA, S. (1986). DNA and amino-acid sequences of 3isopropylmalate dehydrogenase of Bacillus coagulans. Comparison with the enzymes of Saccharomyces cerevisiae and Thermus thermophilus. Biochimica et Biophysica Acta 867, 36-44.

Sekiguchi, T., Suda, M., IshiI, T., Nosoh, Y. \& Tsuda, K. (1987). The nucleotide sequence of 3-isopropylmalate dehydrogenase gene from Bacillus caldotenax. Nucleic Acids Research 15, 853.

Smith, C. L. \& Cantor, C. R. (1987). Purification, specific fragmentation, and separation of large DNA molecules. Methods in Enzymology 155, 449-467.

Somers, J. M., AmzallaG, A. \& Middleton, R. B. (1973). Genetic fine structure of the leucine operon of Escherichia coli $\mathrm{K}-12$. Journal of Bacteriology 113, 1268-1272.

Stieglitz, B. I. \& Calvo, J. M. (1974). Distribution of the isopropylmalate pathway to leucine among diverse bacteria. Journal of Bacteriology 118, 935-941.

UMBARGER, H. E. (1987). Biosynthesis of the branched-chain amino acids. In Escherichia coli and Salmonella typhimurium. Cellular and Molecular Biology, vol. 1, pp. 352-367. Edited by F. C. Neidhardt and others. Washington, DC: American Society for Microbiology.

VieIRA, J. \& Messing, J. (1982). The pUC plasmids, an M13mp7derived system for insertional mutagenesis and sequencing with synthetic universal primers. Gene 19, 259-268.

Williams, I. \& FranK, L. (1975). Improved chemical synthesis and enzymatic assay of $\Delta^{1}$-pyrroline-5-carboxylic acid. Analytical Biochemistry 64, 85-97.

Yanisch-Perron, C., Vieira, J. \& Messing, J. (1985). Improved MI3 phage cloning vectors and host strains: nucleotide sequences of the M13mp18 and pUC19 vectors. Gene 33, 103-119. 